\title{
Karakteristik vegetasi penyusun habitat Lebah Madu Hutan (Apis dorsata. F) di hutan masyarakat Sungai Indragiri Riau
}

\author{
Michael Daru Enggar W, Avry Pribadi
}

\author{
Balai Litbang Teknologi Serat Tanaman Hutan, Jl. Raya Bangkinang-Kuok Km 9, Riau, 28463
}

\begin{abstract}
Habitat of Asian giant honeybee (Apis dorsata) and the forest that surround it play an important role for the development of bees. For local, honey gathered from the bees has important role in enhancing people's live hood. However, studies examine the interaction between the bees and its vegetation is limited. The objection of this study were to (1) determine the number of the sialang trees and (2) to eamine structure of vegetation along the Indragiri river, Riau. The data were collected using the observation method by establishing many observation plots. The data were processed and analyze using quantative descriptive. The results showed that the structure of forests along the Indragiri river are consisted of several types of sialang trees, namely jelemu, arau, and stone wood. The diversity of plants is considerably high, such as Melastoma malabatrichum, rubber, ferns, acacia, and rattan at the seedling level and Macaranga sp, durio $s p$, rubber and meranti at the weaning level. The vegetation is considered still in good condition for bees' hive. Forest vegetation is dominated by the types of meranti, rubber, and the araceae family which can be used for either habitat or bee forage for bees.
\end{abstract}

Keywords: forest giant honey bee, sialang tree, forest honey bee habitat, bee feed

Lebah madu hutan (Apis dorsata) memegang peranan penting bagi keseimbangan ekosistem hutan. Dari berbagai penelitian lebah madu hutan berperan sebagai polinator (penyerbuk) berbagai pohon hutan, tanaman pertanian dan buah-buahan. Lebah madu hutan memanfaatkan hutan sebagai tempat tinggal (pohon sialang) dan tempat mencari makan. Maka apabila salah satu komponen ekosistem tersebut hilang, populasi dari lebah madu hutan akan menurun. Garibaldi (2011) melaporkan penurunan keragaman tumbuhan dan populasi lebah liar maupun serangga penyerbuk disebabkan oleh pengembangan sistem pertanian modern dari berbagai negara. Penggunaan herbisida, pestisida kimia, dan pencemaran sungai berkontribusi terhadap hilangnya spesies tanaman asli setempat, serangga berguna, dan predator penting bagi keseimbangan ekosistem. Upaya konservasi terhadap habitat lebah hutan dan pohon sialang perlu mendapat perhatian lebih untuk kelestarian lebah madu hutan.

Masyarakat yang tinggal di sekitar kawasan hutan sudah sangat akrab dengan lebah hutan dan pohon sialang. Salah satu dari lebah hutan yaitu madu hutan merupakan sumber penghasilan bagi masyarakat dan apabila dirunut lagi akan mempunyai rantai distribusi yang panjang sampai tingkat konsumen. Pemungutan hasil madu hutan sudah menjadi mata pencaharian utama masyarakat khususnya pemanjat pohon sialang yang tinggal di sekitar hutan. Menurut Purnomo (2000), produksi madu lebah hutan di tingkat petani mampu mencapai $605.500 \mathrm{~kg} /$ tahun. Apabila dihitung dalam penghasilan bulanan dengan harga madu hutan saat ini $\mathrm{Rp} 100.000 / \mathrm{kg}$ maka diperkirakan dalam 1 bulan terjadi perputaran uang mencapai 5 milyar lebih dari perdagangan madu hutan. Hal ini tentu menjadikan madu lebah hutan sebagai komoditi bernilai ekonomi tinggi. Selain itu jika dihitung jasa ekosistem lebah madu hutan tentu nilainya akan sangat besar melebihi harga jual madu.

Penelitian yang mengkaji lebah hutan dan habitat serta lingkungan pendukungnya saat ini masih terbatas. Namun data mengenai kondisi pohon sialang, areal kepungan sialang, dan lingkungan pendukung sangat dibutuhkan oleh para pembuat kebijakan untuk mengatur regulasi konservasi pohon sialang dan lingkungan pendukungnya. Penelitian ini bertujuan mengetahui kondisi pohon sialang dan karakteristik vegetasi penyusun habitat lebah madu di tepi sungai Indragiri, Riau.

\section{METODE PENELITIAN}

\section{Lokasi dan Waktu}

Penelitian ini dilaksanakan di Hutan Masyarakat yang berada sepanjang aliran Sungai Indragiri, Kabupaten Indragiri Hulu, Provinsi Riau. Waktu penelitian dilaksanakan mulai bulan Maret sampai dengan Desember 2016. 


\section{Rancangan Penelitian}

Penelitian ini dilakukan dengan menggunakan metode observasi langsung terhadap komposisi vegetasi di sekitar pohon sialang. Pengambilan data dilakukan dengan melakukan inventarisasi terhadap tumbuhan menggunakan petak ukur persegi bertingkat (nested sampling) sesuai tingkat hidup pohon yaitu semai $(2 \times 2 \mathrm{~m})$ dan sapihan $(5 \times 5 \mathrm{~m})$. Pengambilan sampel petak ukur dilakukan dengan ulangan sebanyak 5 kali. Data semai dan sapihan digunakan untuk mengamati ketersediaan tanaman sumber pakan lebah di sekitar pohon sialang.

\section{Parameter yang diamati}

Data yang diamati dalam penelitian ini yaitu kondisi pohon sialang, tumbuhan penyusun habitat lebah pada fase semai dan sapihan, dan kondisi lingkungan pendukung. Data yang diperoleh diolah dengan menghitung Kerapatan Jenis (K), Kerapatan Relatif (KR), Frekuensi (F), Frekuensi relatif (FR), dan Indeks Nilai Penting (INP). Data jenis tanaman dan kondisi habitat lebah diolah secara tabulasi.

\section{Analisis Data}

Analisis data dilakukan deskriptif kuantitatif untuk melihat potensi tumbuhan sumber pakan lebah dan keragaman hayati tumbuhan penyusun habitat lebah hutan di tepi sungai Indragiri.

\section{HASIL DAN PEMBAHASAN}

\section{Kondisi Pohon Sialang dan Lingkungan Pendukung}

Pohon sialang merupakan sebutan masyarakat Riau untuk pohon yang ditinggali oleh lebah madu hutan (A. dorsata). Menurut Purnomo (2007), potensi pohon sialang di provinsi Riau cukup besar, ditemukan 52 jenis pohon sialang yang tersebar di 8 Kabupaten. Kabupaten dengan jumlah pohon sialang terbanyak adalah Rokan Hulu dengan 515 pohon. Dalam memilih tempat bersarangnya lebah madu hutan memiliki preferensi/kesukaan tersendiri. Ciri pohon yang dipilih menjadi sarang lebah madu hutan yaitu berbatang lurus, tinggi bebas cabang tinggi, pohon dominan berada di tempat terbuka, dan kulit bersih dari benalu (Hadisoesilo, 2007). Lebah hutan banyak ditemukan bersarang di cabang pohon yang diameternya $5-100 \mathrm{~cm}$ dengan sudut kemiringan sekitar $25-35^{\circ}$. Jenis pohon hutan yang menjadi sarang lebah hutan di Riau antara lain beringin (Ficus sp), kempas (Koompasia exelsa), lumbuai (Metroxylon sp), siluang (Polythias hypolenca), jangkang (Dellenia exinia), dan mahang (Macaranga sp) (Hadisoesilo, 2007).

Lebah hutan lebih menyukai kayu jelemu dan kayu batu sebagai tempat membangun sarangnya (Tabel 1). Hal ini diduga karena lingkungan sekitar pohon sialang (kepungan sialang) sudah mengalami perubahan. Perubahan tersebut dapat diakibatkan perubahan fungsi kawasan dari hutan alam menjadi kebun, hilangnya tanaman sumber pakan lebah karena berubah menjadi lahan pertanian dan pemukiman, kabut asap akibat kebakaran hutan dan lahan menyebabkan lebah hijrah ke tempat lain, dan aktivitas penebangan pohon sialang untuk diambil kayunya.

Tabel 1. Pohon sialang dan lingkungan pendukungnya

\begin{tabular}{lllll}
\hline No Plot & Jenis Pohon & Jumlah Koloni Lebah & Tinggi Tempat $(\mathrm{mdpl})$ & Suhu mikro $\left({ }^{\circ} \mathrm{C}\right)$ \\
\hline $\mathbf{1 .}$ & Jelemu & 9 & 21 & $22-26$ \\
$\mathbf{2 .}$ & Arau & kosong & 54 & $26-28$ \\
$\mathbf{3 .}$ & Kayu batu & 20 & 45 & $26-28$ \\
$\mathbf{4 .}$ & Kedondong hutan & kosong & 16 & $27-30$ \\
$\mathbf{5 .}$ & Jelemu & 1 & 16 & $24-27$ \\
\hline
\end{tabular}

Sumber : data primer diolah (2016)

Perubahan fungsi kawasan dari hutan alam menjadi kebun berimbas pada perubahan iklim mikro. Lebah madu hutan membutuhkan iklim mikro tertentu untuk dapat tinggal dengan nyaman di sarangnya. Bahkan menurut Pribadi (2010), hutan memiliki pengaruh sebesar $28,17 \%$ terhadap populasi lebah hutan. Hilangnya daerah kepungan sialang bahkan hanya menyisakan pohon sialang saja mengakibatkan lebah madu hutan hijrah. Nagir (2016) melaporkan di Maros, Sulawesi Selatan, dari 107 sarang A.dorsata bighami hanya 17 sarang saja yang masih dihuni oleh lebah. Pernyataan ini diperkuat oleh pengamatan warga lokal yang menyatakan jumlah koloni a.dorsata bighami lebih tinggi pada bulan April-Agustus ketika curah hujan rendah (Nagir et al, 2016). 


\section{ZONA}

Jurnal Lingkungan

ISSN : 2502-6496 (Print)

Hilangnya sumber tanaman pakan lebah menjadi salah satu faktor penting hijrahnya koloni lebah hutan. Dalam 10 tahun terakhir areal yang dulunya hutan telah berubah fungsi menjadi lahan pertanian, perkebunan, dan pemukiman. Hilangnya tanaman pakan berdampak besar kelangsungan hidup koloni lebah hutan. Seperti hewan dan makhluk lain pangan menjadi hal paling penting bagi perkembangannya. Hilangnya makanan bisa berakibat punahnya suatu spesies hewan tertentu seperti yang sudah terjadi dalam 100 tahun terakhir. Permasalahan ini menjadi serius karena lebah hutan dan serangga penyerbuk lainnya mempunyai andil dalam membantu penyerbukan tanaman perkebunan, buah, dan sayuran. Hal ini tentu perlu menjadi perhatian semua pihak mengenai pentingnya lebah hutan dan lingkungan pendukungnya.

Kabut asap dari kebakaran hutan dan lahan di Riau merupakan bukti keserakahan manusia dalam mengeruk alam. Salah satu peristiwa kebakaran hutan yang cukup besar di Riau terjadi pada tahun 2015. Pada saat observasi di lapangan tahun 2016, kondisi alam masih belum sepenuhnya membaik. Pohon sialang yang sebelum kebakaran tahun 2015 banyak memproduksi madu, pascakebakaran tahun 2016 hampir sebagian besar koloni lebah hutan meninggalkan sarangnya. Perlu penanganan hutan kepungan sialang dengan baik agar lebah madu hutan mau kembali bersarang di situ.

\section{Keragaman Vegetasi}

Wilayah kepungan sialang di tepi Sungai indragiri mempunyai keragaman jenis tumbuhan yang cukup tinggi. Vegetasi penyusun habitat lebah madu hutan tersebut dapat digolongkan dalam vegetasi penyusun hutan dataran rendah. Jenis tanah yang ditemukan di tepi Sungai Indragiri termasuk tanah aluvial yang cukup subur. Hasil pengamatan terhadap tumbuhan pada fase semai yang berada dalam 5 petak ukur tersebut diketahui terdapat 12 tumbuhan penyusun habitat lebah hutan. Tumbuhan tersebut dapat digolongkan dalam semai anakan pohon, semak, dan tumbuhan bawah. Dari hasil analisis vegetasi diketahui kelima plot tersebut didominasi oleh jenis pakis (Stenochlaena palustris) dengan Indeks Nilai Penting (INP) sebesar 34,40\% (Tabel 2). Tumbuhan ini digolongkan dalam keluarga paku-pakuan anggota suku Blechnaceae dapat ditemukan sampai dengan ketinggian $900 \mathrm{~m}$ dpl. Habitat alaminya adalah hutan bekas tebangan, hutan sekunder, hutan bakau, sepanjang tepi sungai, dan tempat terbuka yang dekat dengan sumber air. Kondisi plot pengamatan yang hampir sebagian besar terbuka, membuat jenis tumbuhan ini dapat berkembang dengan sangat cepat sehingga mendominasi lantai hutan.

Tabel 2. Nilai Kerapatan Relatif (KR), Frekuensi Relatif (FR), dan Indeks Nilai Penting (INP) pada tingkat semai

\begin{tabular}{llllll}
\hline No & Jenis & KR & FR & INP & Ket \\
\hline $\mathbf{1 .}$ & Shorea sp & 6,06 & 8,82 & 14,88 & Ankn phn \\
$\mathbf{2 .}$ & Hevea brasiliensis & 9,09 & 11,76 & 20,86 & Ankn phn \\
$\mathbf{3 .}$ & Acacia mangium & 10,61 & 5,88 & 16,49 & Ankn phn \\
$\mathbf{4 .}$ & Polyalthia sp & 4,55 & 5,88 & 10,43 & Perdu \\
$\mathbf{5 .}$ & Melastoma malabathricum & 18,18 & 14,71 & 32,89 & Perdu \\
$\mathbf{6 .}$ & Clidemia hirta & 9,09 & 11,76 & 20,86 & Perdu \\
$\mathbf{7 .}$ & Imperata cylindrica & 7,58 & 8,82 & 16,40 & Rumput \\
$\mathbf{8 .}$ & Colocasia sp & 1,52 & 2,94 & 4,46 & Rumput \\
$\mathbf{9 .}$ & Piper aduncum & 4,55 & 5,88 & 10,43 & Perdu \\
$\mathbf{1 0 .}$ & Schleria sumatrensis & 3,03 & 2,94 & 5,97 & Rumput \\
$\mathbf{1 1 .}$ & Asystasia gangetica & 6,06 & 8,82 & 11,94 & Rumput \\
$\mathbf{1 2 .}$ & Stenochlaena palustris & 19,71 & 14,71 & 34,40 & Pakis \\
& Jumlah & 100 & 100 & 200 & \\
\hline
\end{tabular}

Sumber : data primer diolah (2016)

Hasil pengamatan terhadap tumbuhan pada fase sapihan yang berada dalam 5 petak ukur tersebut diketahui terdapat 9 tumbuhan penyusun habitat lebah hutan. Tumbuhan tersebut kebanyakan adalah anakan pohon dan semak. Dari hasil analisis vegetasi diketahui kelima plot tersebut didominasi oleh jenis mahang (Macaranga sp.) dan karet wildling (Hevea brasiliensis dengan Indeks Nilai Penting (INP) sebesar 39,35\% (Tabel 3). Mahang digolongkan dalam anggota famili Euphorbiaceae genus macaranga. Tumbuhan ini merupakan tumbuhan pioner yang mempunyai kemampuan untuk tumbuh dengan cepat saat mendapat sinar matahari penuh. Mahang dapat ditemukan pada areal bekas tebangan, hutan sekunder, dan ladang yang baru dibuka. Secara ekologis, mahang berperan dalam suksesi tanaman hutan terutama hutan yang bekas terbakar. 
Tabel 3. Nilai Kerapatan Relatif (KR), Frekuensi Relatif (FR), dan Indeks Nilai Penting (INP) pada tingkat sapihan

\begin{tabular}{lllll}
\hline No & Jenis & KR & FR & INP \\
\hline $\mathbf{1 .}$ & Shorea sp & 14,58 & 11,11 & 25,69 \\
$\mathbf{2 .}$ & Hevea brasiliensis & 20,83 & 18,52 & 39,35 \\
$\mathbf{3 .}$ & Acacia mangium & 6,25 & 7,41 & 13,66 \\
$\mathbf{4 .}$ & Gluta renghas & 6,25 & 7,41 & 13,66 \\
$\mathbf{5 .}$ & Macaranga sp & 20,83 & 18,52 & 39,35 \\
$\mathbf{6 .}$ & Phoebe sp & 10,42 & 11,11 & 21,53 \\
$\mathbf{7 .}$ & Ficus $s p$ & 10,42 & 7,41 & 17,82 \\
$\mathbf{8 .}$ & Polyalthia sp & 6,25 & 11,11 & 17,36 \\
$\mathbf{9 .}$ & Calophyllum inophyllum & 4,17 & 7,41 & 11,57 \\
& & 100 & 100 & 200 \\
\hline
\end{tabular}

Sumber : data primer diolah (2016)

\section{Potensi Tumbuhan Sumber Pakan Lebah}

Lebah madu hutan membutuhkan tumbuhan tertentu sebagai sumber makanannya. Lebah madu mengumpulkan nektar dan serbuk sari (pollen) dari bunga atau bagian tanaman lain selain bunga. Hal ini diperkuat dengan pernyataan Delaplane (1998) yang menyatakan pada dasarnya makanan utama lebah madu terdiri dari nektar sebagai sumber energi dan pollen sebagai protein. Menurut Ruttner (1988), nektar adalah cairan manis (karena mengandung berbagai jenis gula) yang dihasilkan tanaman melalui kelenjar nektar, sedangkan tepungsari adalah bagian dari bunga jantan berupa butiran yang umumnya berukuran sangat kecil menyerupai debu. Kedua bahan makanan tersebut dikumpulkan lebah untuk kelangsungan hidupnya. Nektar dimanfaatkan oleh lebah madu sebagai bahan baku madu atau cadangan karbohidrat. Menurut Maurizio (1975), karbohidrat pada madu diperlukan oleh lebah sebagai sumber energi untuk gerak dan aktivitasnya. Sedangkan tepungsari (pollen) merupakan sumber protein yang diperlukan untuk pertumbuhan anak lebah dan perkembangan lebah dewasa. Selain protein, pollen juga mengandung lemak, vitamin, dan mineral yang merupakan nutrisi penting bagi lebah. Pollen mempengaruhi tumbuh dan kembang Trigona spp, serta bermanfaat memperbaiki jaringan tubuh dan menjalankan fungsi tubuh lainnya.

Areal kepungan sialang di tepi sungai Indragiri memiliki potensi tumbuhan sumber pakan lebah. Hasil pengamatan menunjukkan terdapat beragam tumbuhan yang dapat menjadi sumber pakan lebah. Tumbuhan yang potensial sebagai sumber pakan lebah hutan adalah tumbuhan yang mampu mensekresikan nektar dan pollen sepanjang tahun. Pengamatan pada 5 plot sampel diketahui tumbuhan potensial sebagai sumber nektar yaitu Acacia mangium, Acacia crassicarpa, kelapa, senduduk, karet, dan durian (Tabel 4). Sedangkan tumbuhan potensial sebagai sumber pollen yaitu kelapa, kelapa sawit, putri malu, Clidemia sp, dan rerumputan. Sebagian besar tumbuhan yang ditemukan dalam plot tersebut merupakan tumbuhan pioner hasil dari suksesi sekunder bukan tumbuhan asli ekosistem tersebut, sebagian tumbuhan merupakan komoditas perkebunan dan Hutan tanaman.

Tabel 4. Tumbuhan Pakan Lebah Potensial di Sekitar Pohon Sialang

\begin{tabular}{lllll}
\hline No & Jenis & Nektar & Pollen & Masa Sekresi \\
\hline 1 & Meranti & + & - & \\
2 & Mahang & + & - & Spjg thn \\
3 & Kelapa & + & + & Spjg thn \\
4 & Acacia mangium & + & - & Spjg thn \\
5 & Acacia crassicarpa & + & - & Spjg thn \\
6 & Keruing & + & - & \\
7 & Kelapa sawit & - & + & Spjg thn \\
8 & Karet & + & - & Sep-Okt \\
9 & Durian & + & - & Juni dan Sept \\
10 & Senduduk & + & + & Spjg thn \\
11 & Putri malu & - & + & Spjg thn \\
12 & Ashoka & + & - & Spjg thn \\
13 & Clidemia sp & + & + & Spjg thn \\
14 & Bitanggur & + & + & Spjg thn \\
15 & Rerumputan & - & + & Spjg thn \\
\hline
\end{tabular}

Sumber:data pengamatan lapangan, 2016 


\section{ZONA}

Jurnal Lingkungan

ISSN : 2502-6496 (Print)

Preferensi lebah madu terhadap jenis tanaman tertentu ditentukan oleh beberapa faktor seperti jumlah dan konsentrasi gula, aroma nektar, wangi bunga, warna bunga, jumlah dan kualitas serbuk sari, dan lain sebagainya (Neuphane, 2006). Tanaman yang tersedia melimpah belum tentu dipilih oleh lebah madu sebab lebah madu juga memperhitungkan nilai gizi dari makanan yang dihisap. Meskipun demikian, sebuah studi yang dilakukan oleh Pribadi dan Wiratmoko (2019) menyatakan bahwa secara umum tidak ada perbedaan yang nyata antara beberapa parameter madu hutan di seluruh Riau jika menggunakan SNI 8664:2018. Secara alamiah, lebah hutan telah mengembangkan mekanisme pertahanan diri dengan kondisi lingkungan yang berubah. Tetapi dikhawatirkan apabila luasan dari kepungan sialang semakin sedikit dikhawatirkan lebah hutan akan semakin tersisih bahkan bisa punah. Maka perlu dilakukan langkah konservasi terhadap pohon sialang dan hutan kepungan sialang untuk kelestarian lebah madu hutan.

\section{KESIMPULAN}

Kondisi pohon sialang di hutan masyarakat tepi sungai Indragiri masih cukup bagus dengan ditemukannya sarang lebah madu hutan. Jenis pohon sialang yang diobservasi yaitu jelemu, kayu batu, kedondong hutan, dan arau. Demikian juga kondisi vegetasi penyusun habitat lebah hutan masih cukup bagus dengan dominasi dengan INP pada fase semai dan dengan INP pada fase sapihan. Beberapa ragam tumbuhan tersebut, tumbuhan potensial sebagai sumber nektar yaitu akasia, kelapa, karet, senduduk, dan durian. Selain itu, tumbuhan sumber pollen potensial yaitu kelapa, kelapa sawit, putri malu, senduduk, dan Clidemia sp.

\section{UCAPAN TERIMAKASIH}

Kami mengucapkan terimakasih kepada Kepala Balai Litbang Teknologi Serat Tanaman Hutan, Ir.R.Gunawan Hadi Rahmanto atas dukungannya dalam penelitian ini. Bapak Drs. Purnomo selaku peneliti yang telah membimbing kami dan memberikan ide bagi karya kami. Tim Teknisi Litkayasa, Bapak Syasri Janetta S.P, Suhendar, serta rekan-rekan lain yang membantu proses pengambilan data lapangan.

\section{DAFTAR PUSTAKA}

Delaplane, K.S. (1998). The small hive beetle, Aethina tumida, in southeast. Am. Bee J, 138 : 884-885

Dietz, A. 1975. Nutrition of the Adult Honey Bee. Dadant and Sons Hamilton, Illonois

Garedew, A, Schmolz, E, and Lamprecht I. 2003. The antimicrobial activity of honey of the stingless bee Trigona spp. Journal of Apicultural Science 47 (1): 37-49

Garibaldi LA, Stefan-Dewenter I, and Kremen C. 2011. Stability of pollination services decreases with isolation from natural areas despite honey bee visits. Ecol Lett 14: 1062-1072

Hadisoesilo, S., \& Kuntadi. (2007). Kearifan Tradisional Dalam Budidaya Lebah Hutan (Apis dorsata).

Kuntadi. (1993). Pengambilan madu lebah Apis dorsata di daerah Riau. Komunikasi, tahun VIII (2) : 19-23. Balai Penelitian Kehutanan di Aek Nauli, Sumatra Utara

Maurizio, A. 1975. How Bees Make Honey. In : Crane, E.(ed.): Honey, A Comprehensive Survey. Chapter Z. Heinemann, London.

Nagir, M. T., Atmowidi, T., \& Kahono, S. (2016). The distribution and nest-site preference of Apis dorsata binghami at Maros Forest, South Sulawesi, Indonesia. Journal of Insect Biodiversity, 4(23), 1-14.

Neupane, K., \& Dhakal, D. (2006). Foraging preference of giant honeybee, Apis dorsata F., to selected horticultural crops. Journal of the Institute of ..., 92, 87-92.

Nye, W. P. and O Mackensen. 1970. Selective Breeding of Honeybees for Alfalfa Pollen Collection Region. J. Apriaries 9:61-64

Pavord, A.V. (1970). Bees and beekepping. Book Published by Cassel.

Pervical, M.S. 1955. The Presentation of Pollen in Certain Angiosperm and its Collecttion by Apis mellifera. New Phytal. 54 : 353-368 
Pribadi A. 2020. The influence of vegetation compositions on Asian giant honey bee (Apis dorsata Fabr.) in Kampar Regency. IOP Conf Ser Earth Environ Sci [Internet]. 2020;533:12045. Available from: http://dx.doi.org/10.1088/1755-1315/533/1/012045

Pribadi, A. dan Wiratmoko, M.D. 2019. Karakteristik Madu Lebah Hutan (Apis Dorsata Fabr.) dari Berbagai Bioregion di Riau. Jurnal Penelitian Hasil Hutan Vol. 37 No. 3: 185-200

Purnomo, 2003. Potensi dan Peluang Usaha Perlebahan di Areal HTI Acacia mangium wild. Prosiding Temu Usaha Perlebahan 29 Juli 2003, Jakarta

Purnomo, Rochmayanto, Y., Junaedi, A., Aprianis, Y., dan Suhendar. 2007. Peta Sebaran Koloni Lebah Hutan (Apis dorsata) dan Data Produksi Madu di Riau ed 1. Laporan Hasil Penelitian Balai Penelitian Hutan Penghasil Serat, Kuok. Tidak dipublikasikan

Purnomo. 2010. Potensi Nektar Pada Hutan Tanaman Jenis Acacia crassicarpa untuk Mendukung Perlebahan. Laporan Hasil Penelitian Balai Penelitian Hutan Penghasil Serat, Kuok (tidak dipublikasikan)

Ruttner, F. 1988. Biogeograpy and Taxonomy of Honeybees. Berlin : Springer Verlag

Salmah. S, 1992. Lebah, Pengembangan dan pelestariannya. Pidato Pengukuhan guru besar tetap dalam ilmu biologi pada FMIPA Universitas Andalas. Padang.

Shuel, R W. 1992. The Production of nectar and pollen. In : Graham and Dadant \& Sous (ends) : The Hive and the Honey Bee. Chapter 10. Dadant and Sous. Hamilton, YLL.

Winston, M.L. 1987. The Biology of the Honey Bee. Harvard Univ. Press. Cambridge, England.

Wongsiri, S and Tangkanasing. 1987. Apis cerana F. Beekeeping in Thailand: unit Chulalongkom University, Bangkok 